\title{
KOTA-KOTA EKS KERESIDENAN KEDU (KAJIAN MORFOLOGI KOTA BERSEJARAH)
}

\section{THE FORMER KERESIDENAN KEDU CITIES (A STUDY ON THE MORPHOLOGY OF HISTORIC CITY)}

\author{
Dwi Pradnyawan \\ Departemen Arkeologi, Fakultas Ilmu Budaya, Universitas Gadjah Mada, Indonesia \\ dwi-pradnyawan@ugm.ac.id
}

\begin{abstract}
The cities of the former Kedu Residency are part of cities in Java that have experienced growth and change over time. Although not a big cities in its time, the cities of the former Kedu Residency show an important role in the interior of Central Java. Its distinctive history in the 19th and 20th centuries formed a city center with an interesting city structure to study. This study aims to study the urban centers of the former Kedu Residency, namely the City of Magelang, Purworejo, Temanggung, Wonosobo, and Kebumen through urban morphology approach by observing the forms (morpho) of the city, such as urban tissue or city shaped, road tissue, land arrangements and buildings. The morphology analysis of the city in the urban centers of the former Kedu Residency shows the interesting facts, namely the development of the city, specifically the city center, from time to time while maintaining the basic characteristics of the traditional city morphology.
\end{abstract}

Keywords: Former Keresidenan Kedu cities; city centre; urban morphology

\section{ABSTRAK}

Kota-kota eks Keresidenan Kedu merupakan bagian dari kota-kota di Jawa yang mengalami perkembangan baik itu pertumbuhan dan perubahan dari waktu ke waktu. Walaupun bukan merupakan kota-kota yang besar pada masanya, kota-kota eks Keresidenan Kedu menunjukkan peranan yang penting pula di wilayah pedalaman Jawa Tengah. Sejarahnya yang khas pada abad ke-19 dan ke-20 membentuk pusat kota dengan tata kota yang menarik untuk dikaji. Penelitian ini berupaya melakukan kajian terhadap pusat-pusat kota eks Keresidenan Kedu, yakni pada Kota Magelang, Purworejo, Temanggung, Wonosobo, dan Kebumen melalui pendekatan morfologi kota dengan mengamati bentuk-bentuk (morfo) penyusun kota, seperti urban tissue atau city shaped, jaringan jalan, tata lahan dan bangunan-bangunan. Analisis morfologi kota pada pusatpusat kota eks Keresidenan Kedu memperlihatkan adanya fakta yang menarik yakni perkembangan kota, secara spesifik pusat kotanya, dari ke waktu dengan tetap mempertahankan karakteristik dasar morfologis kota tradisional.

Kata Kunci : Kota eks Keresidenan Kedu; pusat kota; morfologi kota

$\begin{array}{ll}\text { Artikel Masuk } & : 20-03-2019 \\ \text { Artikel Diterima } & : 21-10-2019\end{array}$ 


\section{PENDAHULUAN}

Kajian arkeologi membagi data ke dalam beberapa jenjang artefak yang bersifat portable atau mikro, fitur yang merupakan tinggalan manusia yang nonportable atau tidak dapat dipindahkan dari matriksnya. Ekofak yang merupakan tinggalan non-artefaktual atau aspek alam namun memiliki keterkaitan dengan budaya manusia. Situs merupakan kumpulan (cluster) dari artefak, fitur, dan ekofak. Kawasan merupakan kumpulan dari situs (Sharer, 2010, hlm. 60-65).

Salah satu yang menarik dari jenjang tersebut adalah kajian mengenai kawasan atau arkeologi kawasan. Arkeologi kawasan menelaah kumpulan dari situs-situs, memperhatikan hubungan antar situs, fitur-fitur yang ada, hubungannya dengan lingkungan alam serta budaya manusia yang bernaung pada suatu wilayah tertentu. Salah satu bentuk kajian kawasan tersebut adalah kajian kawasan perkotaan dalam arkeologi, dimasukkan dalam kajian arkeologi perkotaan (urban archaeology). Arkeologi perkotaan secara khusus mengamati wujud fisik kota dengan bentuknya yang beragam dengan berbagai tingkatan pengamatan, baik dari pengamatan secara mendetail pada suatu artefak, bangunan, struktur hingga pola dalam suatu kawasan kota yang luas (Adrisijanti, 2000).

Pengamatan paling sempit dalam arkeologi perkotaan adalah pembahasan mengenai segala artefak mudah berpindah yang diciptakan untuk mendukung kehidupan manusia, seperti barang-barang kebutuhan hidup sehari-hari manusia di wilayah perkotaan. Pengamatan yang lebih besar terkait umumnya dengan berbagai bentuk bangunan dan struktur atau feature (constructed feature) yang menunjang kehidupan perkotaan, seperti bangunan dengan berbagai fungsi seperti rumah atau perkantoran. Struktur terkait dengan berbagai kebutuhan seperti jembatan, saluran air, dan dam atau bendungan. Pengamatan yang lebih luas terkait dengan kota sebagai kawasan merupakan kumpulan dari bangunan atau struktur, menunjukkan suatu pola tertentu secara spasial dengan fungsifungsi tertentu.

Arkeologi perkotaan tidak saja mengamati wujud fisiknya secara an sich namun juga fungsi dan juga transformasinya secara spasial dan temporal. Berdasarkan kajian ini, maka kajian arkeologi perkotaan juga mencari hubungan antara bentuk tangible kawasan dengan nilai atau bentuk intangiblenya terkait dengan kehidupan manusia di kawasan perkotaan.

Bidang ilmu lain yang terkait dengan perkotaan adalah bidang kajian morfologi yang umumnya terkait dengan kajian arsitektur kawasan atau perencanaan kawasan. Kajian morfologi, terutama morfologi perkotaan (Oliviera, 2016), memiliki kesamaan dengan arkeologi perkotaan dalam pengamatannya pada elemen-elemen yang membentuk sebuah perkotaan. Serupa dengan kajian arkeologi perkotaan, kajian morfologi perkotaan memperhatikan pula satu per satu elemen kota dari satu bangunan, kumpulan bangunan, kawasan dengan fungsi tertentu ( $\mathrm{plot} / \mathrm{lot}$ ), hingga urban tissue sebagai gambaran wajah kota dari angkasa.

Jika dalam arkeologi bisa dikatakan lebih tertuju pada beragam rekonstruksi atau pelestarian warisan budaya kawasan perkotaan, maka kajian morfologi perkotaan lebih menekankan pada perencanaan dan pengelolaan 
wilayah untuk menjawab tantangan kehidupan perkotaan dan masa depan kawasan perkotaan itu sendiri.

Kawasan perkotaan berbeda dengan kawasan lainnya, seperti kawasan pedesaan, terutama atas dasar kompleksitas aspek yang ada pada kawasan perkotaan. Salah satu aspek yang penting adalah morfologi atau bentuk tata ruang atau bentuk fisik yang spefisik. Morfologi adalah gambaran atau bentuk fisik dari kota dengan berbagai elemennya yang merupakan representasi dari berbagai aspek kehidupan masyarakat kota yang heterogen seperti aspek ekonomi, sosial, budaya, politik, sejarah, seni-arsitektur dan keagamaan (Oliviera, 2016, hlm. 3145; Sunaryo, 2013, hlm. 78).

Salah satu kawasan perkotaan yang menarik adalah kawasan kota yang memiliki aspek kesejarahan tertentu, seperti kawasan perkotaan di Jawa yang dulunya merupakan pusat kekuasaaan atau pemerintahan baik tingkat kerajaan atau daerah-daerah dibawahnya. Kota-kota seperti ini memiliki rangkaian sejarah yang panjang sejak berdiri hingga masa kini.

Kota-kota yang dimaksud adalah kota-kota di Jawa seperti yang kita ketahui saat ini. Beberapa kota tersebut bahkan memiliki riwayat sejarahnya tersendiri seperti kota-kota bekas kerajaan Mataram Islam seperti Kota Gede, Plered, Kartasura, dan Surakarta, dan kemudian Yogyakarta sebagai kota baru setelah pembagian kekuasaan Mataram Islam (Adrisijanti., 1998, hlm. 2000). Selain kota-kota tersebut kota-kota tua seperti Demak, Kudus, Pati, Jepara, Cirebon dan juga Banten juga memiliki riwayat sebagai kota-kota penting dalam sejarah Jawa mulai abad ke-16 Masehi (Ikaputra, 1995, hlm. 23-40; Wardani, 1991).

Selain kota-kota tersebut, yang umumnya dipandang sebagai kota besar pada masanya, juga terdapat kota-kota kecil yang merupakan bagian dari kota-kota besar tersebut. Kawasan perkotaan yang menarik untuk dikaji adalah kota-kota eks Keresidenan Kedu, yakni Kota Magelang, Purworejo, Temanggung, Wonosobo dan Kebumen. Setiap kota tersebut memiliki sejarahnya tersendiri yang menarik untuk ditelaah lebih mendalam. Kota-kota tersebut mengalami pertumbuhan, perkembangan maupun perubahan yang nampak dari elemenelemen kota atau morfologinya yang beragam. Setiap elemen dari kota tersebut menyimpan dan menunjukkan memori sejarahnya tersendiri yang berbeda atau khas dari masa ke masa.

\section{METODE}

Tulisan ini merupakan upaya membandingan elemen-elemen perkotaan dalam kajian arkeologi perkotaan dengan kajian urban morfologi dalam rangka memperkaya khazanah kajian arkeologi perkotaan yang selama ini telah dilakukan di Indonesia. Meskipun demikian, kajian urban morfologi yang dilakukan baru akan dilakukan pada analisis dasar unsur morfologi kawasan yang akan diteliti.

Penelitian yang dilakukan bersifat deskriptif analisis dengan mendasarkan pada pengamatan lapangan, dokumentasi visual, dan pengamatan citra satelit pada pusat kota kota-kota eks Keresidenan Kedu, yakni Magelang, Purworejo, Temanggung, Kebumen, dan Wonosobo. Tahapan penelitian yang dilakukan yakni: Pertama, mengamati dan mendeskripsikan unsur morfologi pada pusat 
kota kota-kota eks Keresidenan Kedu yang meliputi pengamatan pada unsur bangunan, blok/ plot, jaringan jalan, elemen alam (natural context), dan bentuk urban tissue. Kedua, mengamati dan mendeskripsikan data arkeologi terkait arkeologi perkotaan dalam hal ini elemen catur tunggal beserta kondisi atau keadaan terkininya seperti, bangunan-bangunan, toponimi, jaringan jalan, atau fitur-fitur lainnya, sebagai pendukung kota. Ketiga, melakukan analisis perbandingan (comparative analysis) secara kualitatif antara unsur morfologi perkotaan dengan data arkeologi. Analisis perbandingan diharapkan dapat menjelaskan posisi data arkeologi dalam konteks tata ruang kota yang lebih luas serta melihat perubahan-perubahan yang terjadi pada kota-kota tersebut.

\section{HASIL PENELITIAN}

\section{Kota-Kota Eks Keresidenan Kedu}

Magelang, Purworejo, Temanggung, Wonosobo, dan Kebumen merupakan kota-kota yang dulunya adalah bagian dari Keresidenan Kedu. Keresidenan merupakan salah satu bentuk wilayah administratif pada masa Hindia-Belanda yang merupakan kelompok dari wilayah-wilayah setingkat kabupaten pada saat ini.

Keresidenan Kedu pada awalnya adalah pembagian wilayah administratif yang menaungi wilayah Magelang dan Temanggung. Namun sejak tahun 1901, Keresidenan Kedu digabungkan dengan wilayah Keresidenan Bagelen yang meliputi wilayah Purworejo, Kebumen, dan Wonosobo. Keresidenan Kedu yang terbentuk pada tahun 1901 kemudian berpusat di Kota Magelang (Bappeda Purworejo, 1982; Musadad, 2001, hlm. 30-36).

Wilayah-wilayah eks Keresidenan Kedu tersebut memiliki sejarah yang berbeda antara satu wilayah dengan wilayah lainnya. Beberapa wilayah memiliki sejarah yang terkait dengan masa Mataram Kuno, seperti wilayah Temanggung (Rizqi, 2013) dan kota Purworejo dengan masa Mataram Islam ketika berkuasa di wilayah Jawa Tengah. Namun sejarahnya yang lebih jelas tentang kota-kota eks Keresidenan Kedu dapat dipastikan terkait dengan masa Mataram Islam hingga pada masa Palihan Nagari yang membagi wilayah Jawa Tengah ke dalam dua wilayah besar yakni Kasultanan Yogyakarta dan Kasunanan Surakarta.

Wilayah-wilayah tersebut juga memiliki keterkaitan sejarah dengan Perang Diponegoro atau Perang Jawa. Perang tersebut tidak saja membawa dampak yang sangat hebat bagi kehidupan di Jawa namun juga membawa perubahan yang penting terhadap perkembangan tata kotanya. Kota seperti Magelang dan Purworejo merupakan kota-kota yang dibentuk atau dikembangkan oleh pemerintah Hindia-Belanda untuk keperluan pertahanan militer pada saat atau setelah Perang Jawa. Peristiwa sejarah dalam hal ini membawa dampak bagi bentuk tata kotanya (Prasetyo Aji, 2013; Musadad, 2001).

Secara umum berdasarkan tahap sejarahnya, kota-kota eks Keresidenan Kedu dapat dibagi kedalam beberapa fase yang nampak dari bentuk-struktur tata kotanya, yakni periode bentuk tradisional, periode Hindia-Belanda dan periode pasca Hindia Belanda. Bentuk tradisional adalah kota dengan ciri-ciri tradisional yang merupakan bentuk warisan kerajaan-kerajaan Islam Jawa. Bentuk periode 
Hindia-Belanda adalah kota yang berkembang dengan masuknya elemen-elemen baru Hindia-Belanda yang masuk pada kota-kota tradisional. Bentuk pasca Hindia-Belanda adalah bentuk tata kota ketika memasuki masa kemerdekaan Republik Indonesia hingga masa kini.

\section{Pusat Kota Eks Kerisedenan Kedu: Komposisi Catur Tunggal}

Pengamatan terhadap suatu kota merupakan pengamatan kompleks yang mencakup berbagai aspek kehidupan yang saling terkait satu dengan lainnya. Demikian pula halnya dengan kota-kota eks Keresidenan Kedu, terdapat beragam aspek dalam pembahasan mengenai kotanya. Pusat Kota di kota-kota eks Keresidenan Kedu dapat dipastikan berkembang dari bentuk pusat kota kuno Islam di Jawa pada umumnya. Pusat kota di Jawa dan kota eks Keresidenan Kedu merupakan inti dari kota dan umumnya hampir setiap aspek kehidupan terpusat di pusat kota tersebut atau wilayah-wilayah disekitarnya.

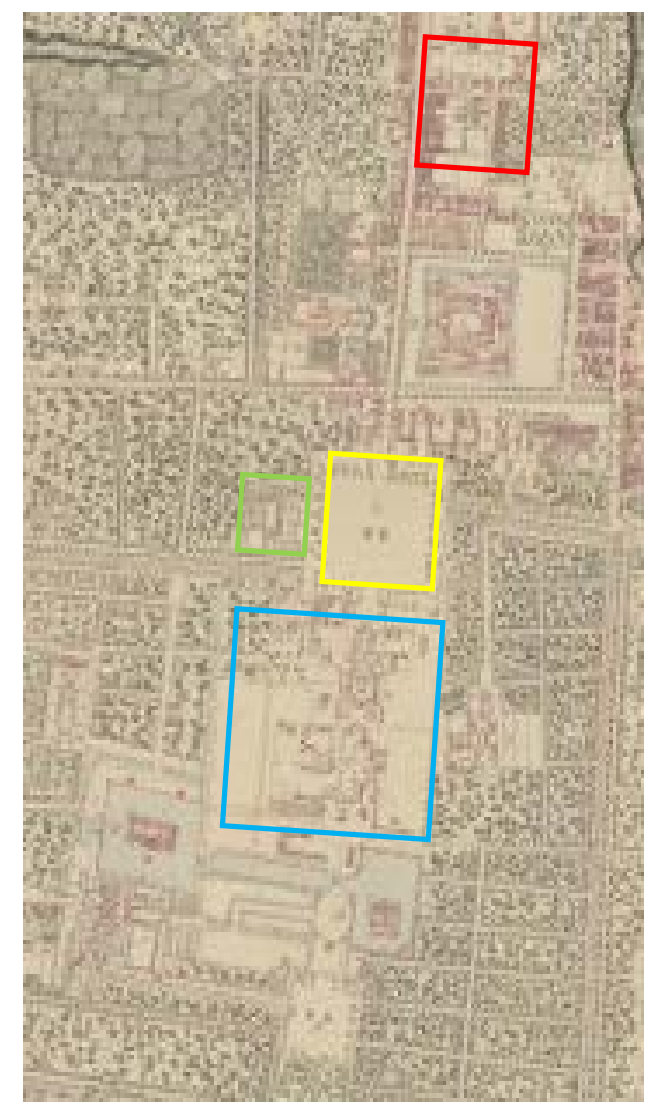

Gambar 1. Posisi Catur Tunggal pada Kota Yogyakarta. Alun-alun (kuning), Tempat penguasa (biru), Masjid (hijau), Pasar (Merah) (Sumber Peta: KITLV, Leiden dengan Modifikasi)

Pusat kota-kota di Jawa, baik kota-kota tradisional atau pra HindiaBelanda, menunjukkan bentuknya dengan komponen inti yang disebut dengan catur tunggal atau fourth compartment yang berarti empat komponen dalam satu kesatuan (Ikaputra, 1995, hlm. 23-29). Komponen tersebut adalah alun-alun, tempat penguasa (kedaton atau kabupaten), tempat ibadah masjid, dan pusat ekonomi yakni pasar. Komponen catur tunggal menunjukkan konsistensi pada 
posisinya. Alun-alun selalu berada di tengah dari komponen lainnya. Tempat penguasa berada di posisi utara atau selatan. Masjid selalu berada di sebelah barat. Sedangkan pasar dapat berada di posisi timur atau utara. Dari semua komponen, tempat penguasa dan pasar terkadang posisi dapat berpindah (Gambar 1).

Kota-kota di Jawa yang merupakan warisan dari kota kuno, termasuk kota-kota eks Keresidenan Kedu, pasti memiliki alun-alun dengan beberapa karakteristik yang khas, yakni alun-alun yang merupakan ruang terbuka yang cukup luas disertai dengan vegetasi yang khas, yakni pohon beringin yang umumnya terdapat di tengah alun-alun atau disekelilingnya (Handinoto, 1992, hlm. 1-15; Ikaputra, 1995, hlm. 33-35) (Gambar 2). Alun-alun merupakan ruang terbuka yang awalnya diperkirakan memiliki fungsi khusus yang bersifat politis atau terkait tradisi tertentu. Namun saat ini fungsinya telah berubah menjadi pusat kegiatan yang lebih beragam. Seluruh kota eks Keresidenan Kedu memiliki alun-alun, walau dengan luasan yang beragam.

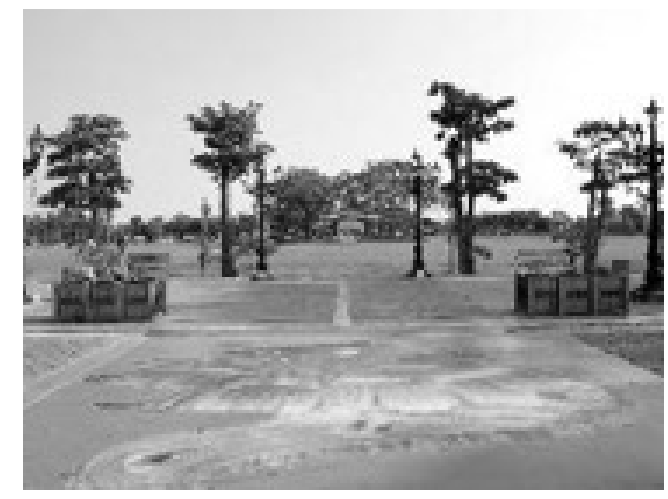

Gambar 2. Alun-Alun Kota Purworejo (Sumber: Penulis 2018)

Tempat penguasa umumnya berada di sebelah selatan atau utara dari alun-alun. Di kota besar, seperti pusat kerajaan di Kasultanan dan Kasunanan, lokasi kedaton atau tempat penguasa selalu berada di sebelah selatan alun-alun utama (Ikaputra, 1995, hlm. 30-32). Pada kota-kota eks Keresidenan Kedu, tempat penguasa adalah tempat para bupati berada, posisinya berada di sebelah utara walau terkadang pada posisi yang berbeda, terutama setelah masuknya pengaruh Hindia-Belanda (Gambar 3).

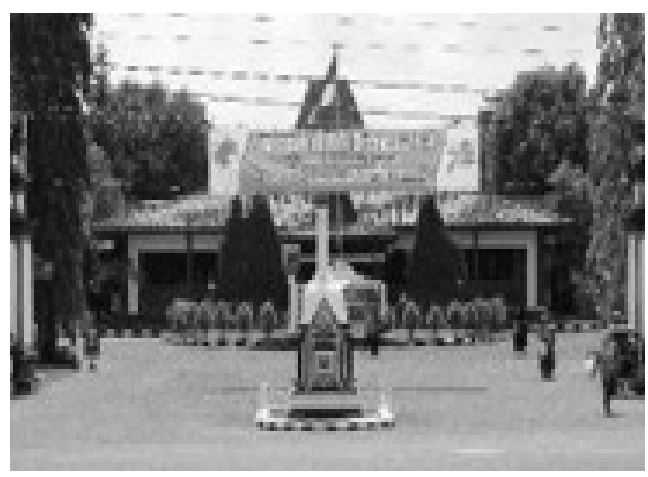

Gambar 3. Kantor Bupati Kebumen (Sumber: Penulis 2018) 
Tempat ibadah dalam konteks pusat kota tradisional selalu merupakan masjid yang mengambil posisi di sebelah barat alun-alun (Gambar 4). Keberadaan masjid menjadi komponen pokok dalam catur tunggal (Ikaputra, 1995, hlm. 35-37). Keberadaan masjid pada kota-kota eks Keresidenan Kedu hampir seluruhnya berada pada sebelah barat alun-alun, kecuali pada kota Wonosobo yang mempunyai dua masjid "besar" satu berada pada posisi barat dan satu pada sisi barat daya (Jannati, 2005, hlm. 29-30).

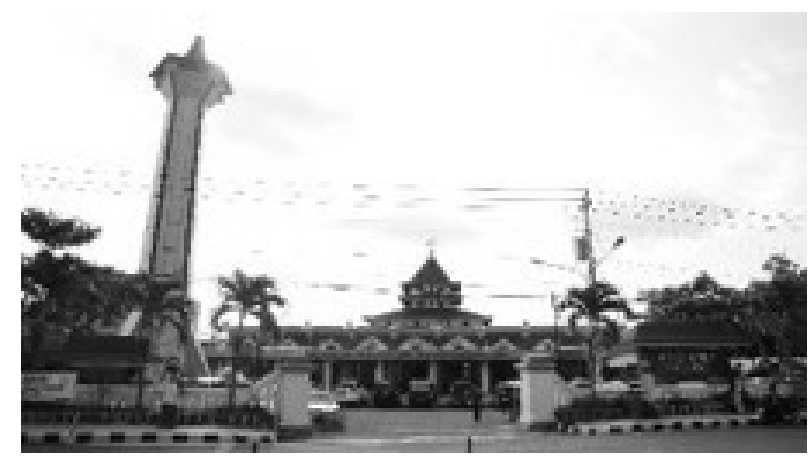

Gambar 4. Masjid Jami Magelang.

(Sumber: Penulis 2018)

Komponen catur tunggal terakhir adalah tempat ekonomi yakni pasar. Pasar adalah pusat perekonomian tempat kegiatan ekonomi terutama perdagangan dilakukan pada tempat ini. Posisinya dapat berada di sebelah timur atau utara alun-alun (Ikaputra, 1995, hlm. 37-41). Pada pusat kota Kasultanan dan Kasunanan, pasar besar berada di sebelah utara dari alun-alun, namun pada kotakota eks Keresidenan Kedu, pasar pada posisi yang tidak selalu sama. Pasar di kota Kebumen, Purworejo, dan Temanggung posisinya pada sebelah timur (atau timur laut) dari alun-alun. Namun pada kota Magelang dan Wonosobo letaknya berada di sebelah condong ke selatan dari alun-alun. Bentang lahan yang berbeda memungkinkan sekali membawa perubahan pada posisinya.

\section{Pusat-Pusat Kota Eks Keresidenan Kedu: Ruang Pemukiman yang Tumbuh}

Selain komponen catur tunggal yang merupakan elemen inti dari kota tradisional terdapat pula elemen lainnya yang merupakan bagian yang tidak terpisahkan dari pusat kota. Dalam konteks kota, elemen yang juga penting selain catur tunggal adalah pemukiman. Walaupun tidak disebutkan sebagai elemen inti namun keberadaan ruang pemukiman adalah sama pentingnya dengan keempat elemen pokok tersebut. Pemukiman menjadi sarana tempat tinggal bagi penduduk dari kota (Ikaputra, 1995, hlm. 27-29)

Kedaton atau kabupaten pada dasarnya adalah tempat bermukim bagi penguasa dan sanak keluarganya. Umumnya, disekeliling dari tempat penguasa terdapat pemukiman-pemukiman khusus, seperti prajurit atau para abdi yang melayani penguasa (Ikaputra, 1995, hlm. 41-44). Terkadang jenis-jenis pekerjaan 
tertentu menempati ruang-ruang dalam kota, seperti kampung Kauman yang menjadi tempat bermukim para abdi yang mengelola masjid (Zahnd, 2008). Lokasi bermukimnya selalu berdekatan dengan masjid. Keberadaan kampung Kauman pada kota eks Keresidenan Kedu juga nampak dan selalu berdekatan dengan masjid. Indikasi pemukiman tradisional lainnya juga nampak pada kota-kota eks Keresidenan Kedu. Indikasi pemukiman tradisional salah satunya yang jelas nampak pada kota Wonosobo dengan adanya toponimi-toponimi yang masih ada saat ini (Jannati, 2005, hlm. 45-47). Tempat-tempat bermukim yang sering disebut kampung tersebar tidak terlampau jauh dari pusat kota.

Pecinan atau pemukiman orang Cina merupakan salah satu elemen penting yang umumnya selalu menyertai keberadaan pasar (Pratiwo, 2010: passim). Keberadaan orang Cina yang umumnya sebagai pedagang hampir selalu bermukim di kawasan sekitar pasar atau kawasan ekonomi lainnya yang tumbuh kemudian. Pecinan umumnya memiliki ciri khas dari bangunan-bangunannya, terutama arsitekturnya yang merupakan khas bangunan dengan ciri-ciri Cina serta bentuk bangunannya seperti bangunan rumah toko (ruko atau shophouse). Pecinan dapat ditemui pada semua kota eks Keresidenan Kedu (Gambar 5).

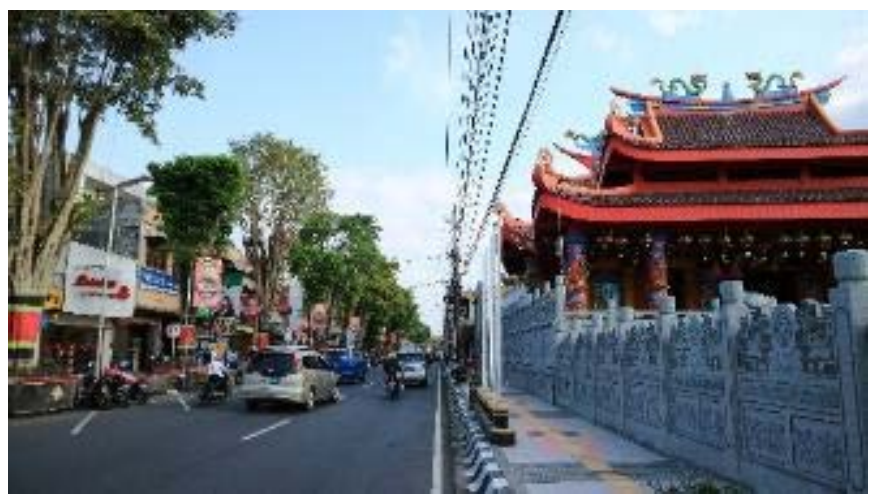

Gambar 5. Suasana Pecinan di Jalan Pemuda, Magelang (Sumber: Penulis 2018)

Pemukiman orang Eropa atau Belanda menjadi ciri dari pusat kota yang datang kemudian pada pusat-pusat kota tradisional. Ketika pemerintahan HindiaBelanda mulai semakin kuat, terutama setelah Perang Jawa atau Perang Diponegoro, pemukiman-pemukiman orang Eropa semakin banyak ditemui pada bagian-bagian tertentu dari pusat kota. Bagian paling mencolok adalah keberadaan kantor atau rumah pejabat Belanda seperti Residen, Asisten Residen atau Kontrolir yang menjadi "tandingan" dari pejabat tradisional seperti Bupati. Pada kota-kota eks Keresidenan Kedu, rumah pejabat Belanda selalu berhadapan atau mendampingi dari kediaman pejabat tradisional. Umumnya ruang pejabat ini mengisi sisi selatan atau timur, seperti pada kota-kota eks Keresidenan Kedu.

Selain kediaman pejabat Belanda, tempat tinggal orang Eropa-Belanda lainnya juga ditemukan. Pada kota-kota eks Keresidenan Kedu, pemukiman ini nampak pada sisi timur, utara dan selatan. Ciri menonjol dari pemukiman ini adalah bentuk atau gaya arsitekturnya yang khas yakni gabungan antara arsitektur tradisional dengan Eropa (gaya arsitektur Indis, gaya Empire atau Gaya kolonial pada awal abad ke-20). Ciri khas lain adalah pemukiman didukung atau 
berdekatan dengan beragam fasilitas publik lainnya, seperti bangunan-bangunan militer, gereja, kantor pos, sekolah, tempat hiburan (bioskop), taman, penjara atau bahkan stasiun kereta api. Pada kota-kota eks Keresidenan Kedu, fasilitas-fasiltas seperti ini dapat ditemui (Sunaryo, 2013, hlm. 81-84) (Gambar 6 dan 7).
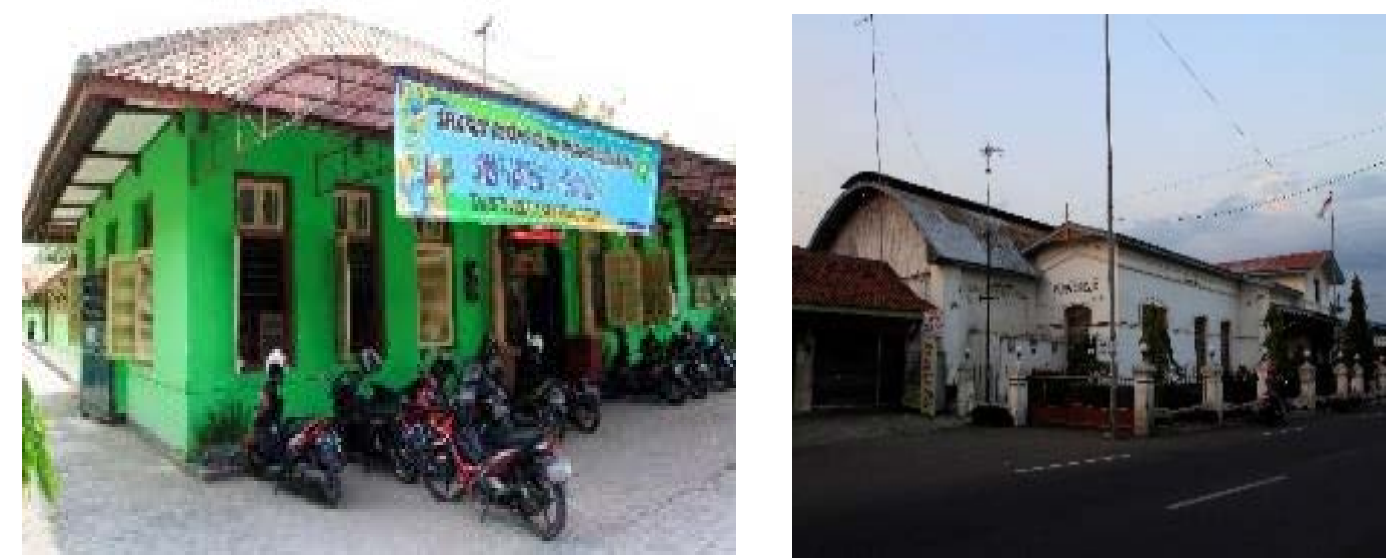

Gambar 6. Kiri :Bangunan Sekolah Lama (SMP 7 Kebumen), Kanan: Bekas Stasiun Kereta Api Purworejo (Sumber: Penulis 2018)

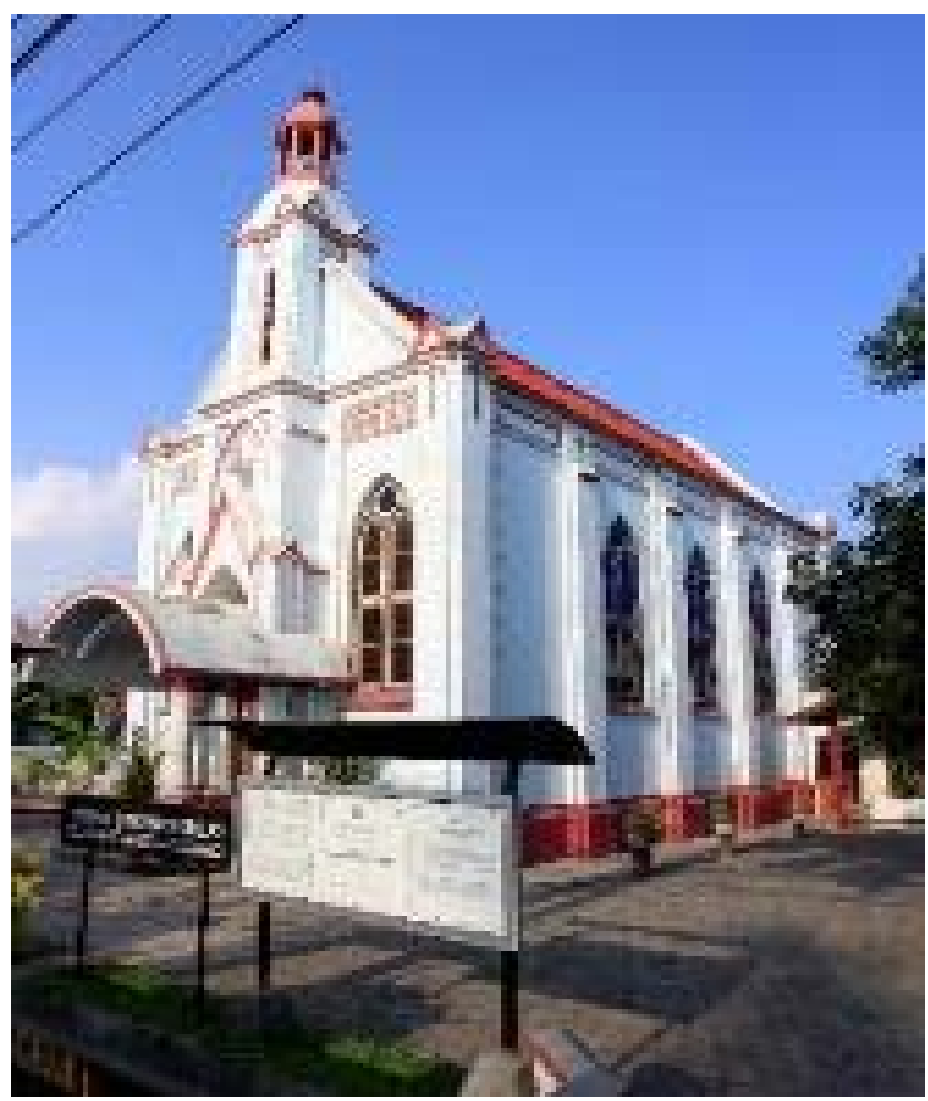

Gambar 7. Bangunan Gereja di Purworejo (Sumber: Penulis 2018) 


\section{PEMBAHASAN}

\section{Morfologi Kota, Data Arkeologi dan Transformasi Kota}

Morfologi kota dengan elemen atau unsur-unsurnya dalam banyak hal terkait dengan arkeologi, terutama dalam hal kajian tentang kawasan perkotaan bersejarah atau kawasan warisan budaya. Kawasan warisan budaya dibentuk dengan adanya nilai sejarah yang kuat disertai dengan adanya jejak-jejak tinggalan manusia yang dapat dimasukkan dalam kategori data arkeologis. Hal ini juga nampak pada kota-kota eks Keresidenan Kedu dengan bentuk yang khas.

Morfologi kota mempelajari bentuk-bentuk kota berdasarkan elemenelemen atau unsur-unsur yang menyusunnya. Elemen-elemen tersebut secara makro (jika dilihat dari angkasa) akan menunjukkan bentuk yang sering disebut sebagai urban tissue atau urban fabric atau city shaped atau "wajah" sebuah kota. Urban tissue menunjukkan (dengan berbagai macam resolusi pengamatan) hirarki wajah kota, dari unsur paling makro hingga ke unsur mikro yang merupakan elemen-elemen penyusun urban tissue tersebut.

Elemen-elemen kota yang membentuk urban tissue merupakan kumpulan elemen yang membentuk jaringan dengan berbagai macam fungsi yang bentuknya dipengaruhi oleh berbagai macam aspek. Elemen kota, secara umum adalah unsur alami (natural context), jalan dan jaringan jalan, blok atau plot/lot atau kawasan, serta struktur atau bangunan (Oliveira, 2016, hlm. 1-30).

Unsur alami atau natural context adalah unsur alam tempat dimana sebuah kawasan perkotaan berada, baik itu bentang lahan tertentu. Bentang lahan marin terkait dengan wilayah pesisir pantai, bentang lahan pengunungan, atau bentang lahan dataran-fluvial dimana unsur-unsur alam tertentu seperti sungai, danau, pantai, bukit, atau gunung menjadi bagian dari pertimbangan pembentukan kawasan perkotaan.

Jalan atau jaringan jalan adalah merupakan sebidang lahan dengan dimensi dan bentuk tertentu (garis lurus atau melengkung) yang dipergunakan untuk akses didalam sebuah kawasan. Jalan atau jaringan jalan merupakan unsur morfologi yang nampak secara makro dan membentuk wajah kawasan.

Blok atau plot/lot merupakan kawasan-kawasan atau zona-zona dengan luas dan fungsi tertentu yang umumnya dibatasi oleh jaringan jalan. Kawasan secara khusus dapat diartikan sebagai ruang-ruang dengan fungsi-fungsi tertentu, seperti ruang publik, ruang pemukiman, ruang industri, ruang terbuka hijau dan lain-lain. Seperti halnya jaringan jalan, blok atau plot merupakan unsur morfologi yang nampak secara makro atau membentuk wajah kawasan.

Unsur yang paling detil dalam unsur morfologi adalah adanya struktur atau bangunan. Struktur seperti jembatan atau dam serta rupa-rupa bentuk bangunan dengan gaya arsitekturnya masing-masing dengan fungsinya merupakan pembentuk kawasan perkotaan paling mikro, dan dapat saja memberikan bentuk pada wajah perkotaan terutama bentuk-bentuknya yang khas dengan dimensi yang luas, contohnya seperti bentuk dengan bentuk denah yang khas.

Unsur alami atau lingkungan alam hampir selalu memiliki keterkaitan dengan data arkeologis, sebagai wadah atau lokasi dari sebuah kawasan atau struktur-bangunan yang memiliki value sejarah dan arkeologis. Kota-kota di Jawa 
selalu terkait dengan bentang alam dan terutama sekali terkait dengan keberadaan sungai-sungai atau sumber air lainnya. Lingkungan alam dalam banyak hal dilupakan sebagai bagian integral dari warisan budaya. Kota-kota eks Keresidenan Kedu seperti pada lampiran dibawah menunjukkan bahwa elemen alam bentang lahan dengan adanya sungai ataupun gunung selalu melekat pada kota-kota eks Keresidenan Kedu.

Sungai dan gunung merupakan unsur alam yang selalu terkait dengan kota-kota eks Keresidenan Kedu. Kota Magelang diapit oleh dua sungai yakni Sungai Progo dan Sungai Elo di sisi timur dan baratnya. Kota Magelang juga amat dekat dengan Gunung Tidar dan pegunungan yang lain. Kota Purworejo pada sisi selatannya mengalir Sungai Bogowonto. Kota Temanggung dan Wonosobo berdekatan dengan bagian hilir Sungai Progo dan berdekatan pula dengan Gunung Sindoro dan Sumbing. Kota Kebumen mengalir Sungai Luk Ulo pada sisi selatannya. Dipilihnya pusat kota dengan unsur alami ini tentunya didasarkan atas pertimbangan-pertimbangan tertentu, salah satunya adalah kemudahan pemenuhan air yang dipergunakan untuk berbagai keperluan pendukung kehidupan di perkotaan. Bahkan untuk kota Magelang dibangun pula fitur-fitur perairan untuk mendukung pemenuhan kebutuhan air tersebut (Prasetyo, 2013: passim).

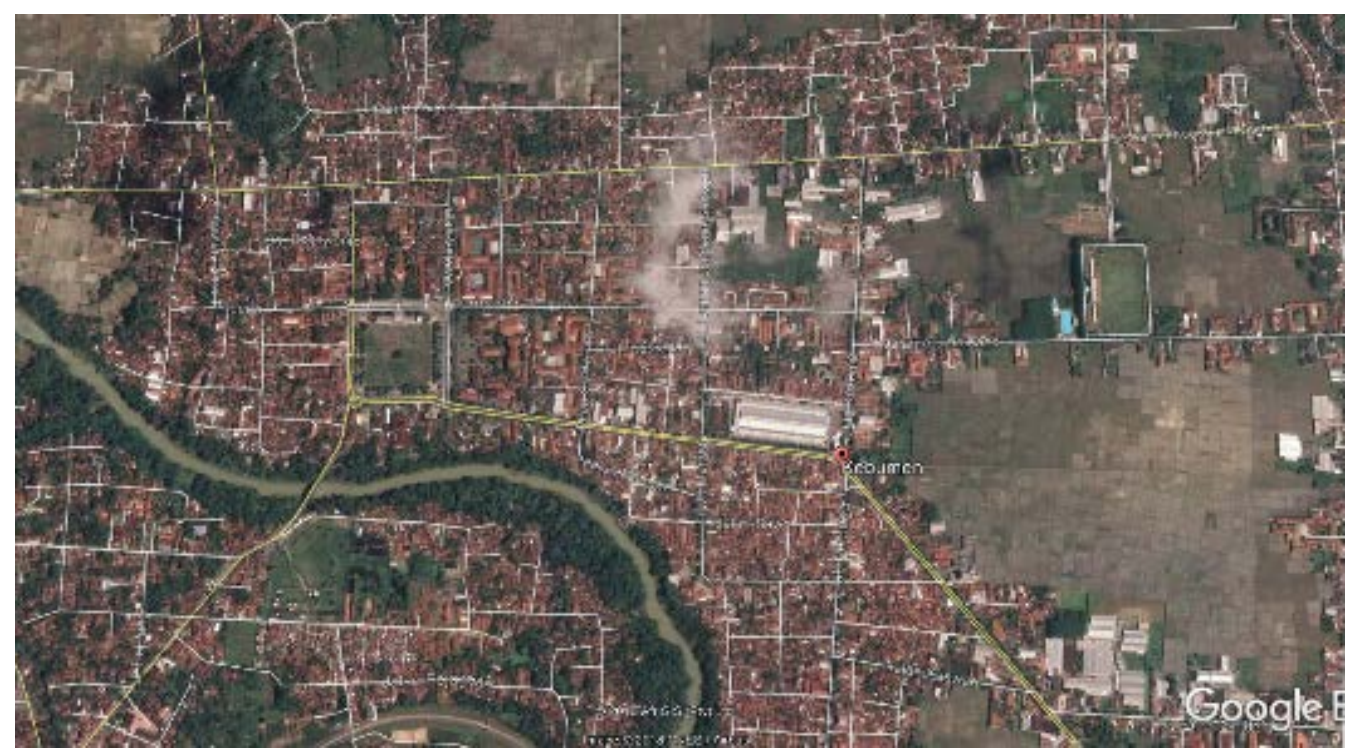

Gambar 8. Citra Google Earth Kota Kebumen menampakkan jaringan jalan tipe grid atau orthogonal atau garis-garis lurus berpotongan. Meskipun terdapat Sungai pada sisi selatan kota, namun bentuk grid tetap diupayakan pada jaringan jalan dan ciri blok atau plot kawasannya. Google Earth memberikan warna garis kuning untuk jalan utama atau jalan arteri primer, dan warna putih untuk jalan kolektor atau jalan penghubung antar wilayah di dalam kota.

(Sumber : Citra Goole Earth Kota Kebumen dengan modifikasi)

Jalan atau jaringan jalan selau ditemui dalam konteks data arkeologi yang disebut fitur atau feature. Jalan atau jaringan jalan dalam kawasan perkotaan bersejarah merupakan salah satu bentuk yang tangible, yang mudah untuk diamati, namun terkadang dilupakan sebagai bagian dari warisan budaya karena banyaknya fokus perhatian pada bentuk warisan budaya lainnya khususnya 
bangunan-bangunan. Jaringan jalan pada kota-kota eks Keresidenan Kedu menampakkan bentuk umum yakni bentuk grid atau orthogonal, dimana pusat kota dikelilingi oleh jaringan jalan berbentuk grid atau garis-garis lurus. Jalanjalan pada wilayah alun-alun atau jalan utama menuju wilayah pusat kota, selalu memiliki dimensi yang lebih lebar dibandingkan sisi kota lainnya.

Meskipun demikian terdapat penyesuaian jaringan jalan dengan bentang lahannya pada kebanyakan kota-kota tersebut, terutama pada sisi pinggiran kotanya. Jalan-jalan yang menjauh dari semua pusat kota eks Keresidenan Kedu menyesuaikan dengan bentang lahannya. Seperti halnya pada Kota Magelang, Temanggung, dan Wonosobo (lihat lampiran). Kota Purworejo dan Kebumen, nampak pula melalukan penyesuaian, namun bentuk jalan orthogonal tetap menjadi ciri kuat dari kedua kota tersebut (Gambar 8 dan 9).

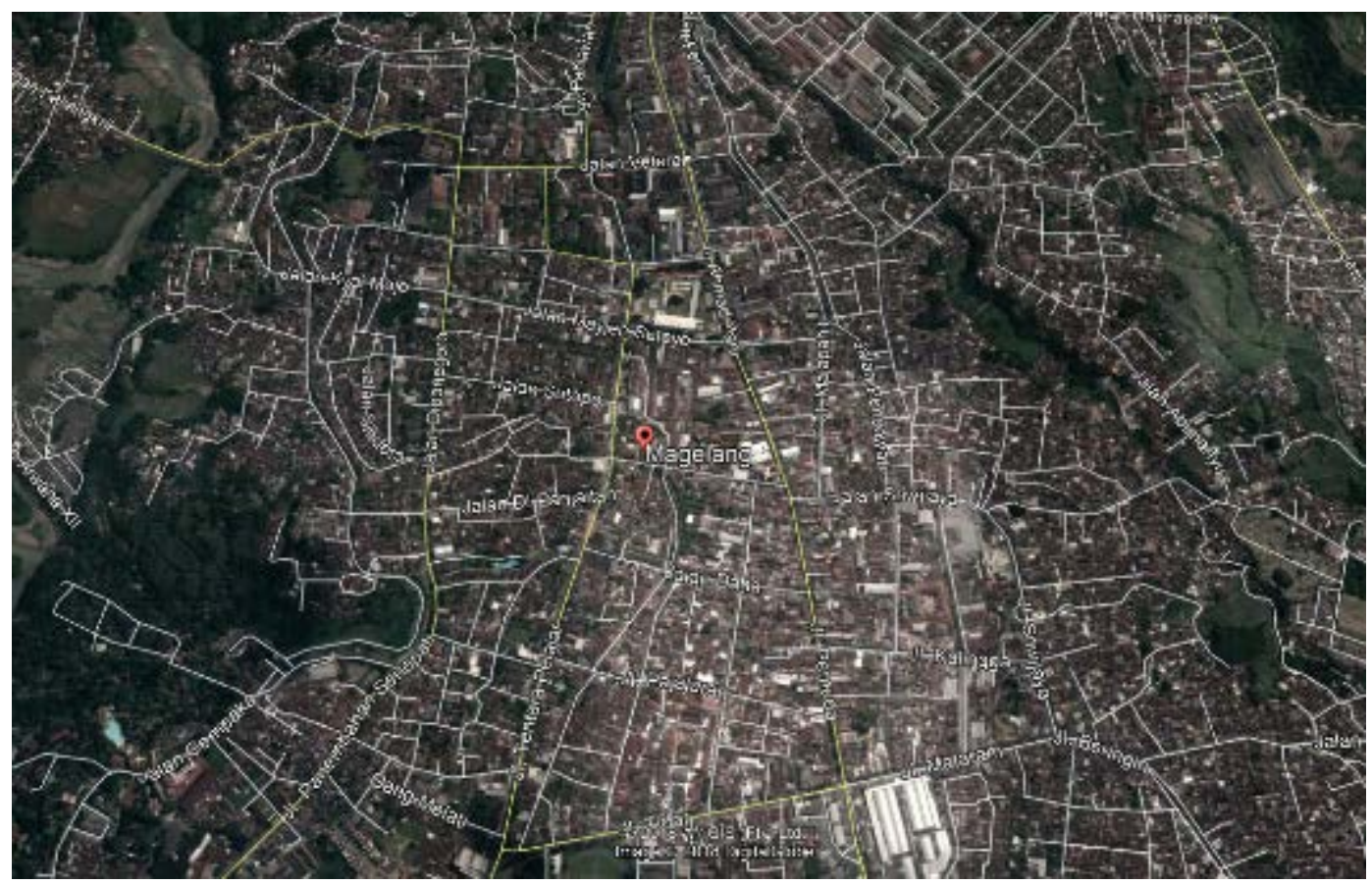

Gambar 9. Citra Google Earth Kota Magelang menampakkan jaringan jalan tipe grid atau orthogonal atau garis-garis lurus berpotongan pada pusat kota dan jalan utama. Namun demikian karena bentang lahannya terdapat penyesuian jalan secara organis (melungkung sesuai kontur atau blok kawasan). Google Earth memberikan warna garis kuning untuk jalan utama atau jalan arteri primer, dan warna putih untuk jalan kolektor atau jalan penghubung antar wilayah di dalam kota.

(Sumber : Citra Goole Earth Kota Kebumen dengan modifikasi)

Blok, plot/ lot, atau zonasi, seperti halnya jalan dan jaringan jalan, juga merupakan bagian dari data arkeologi. Blok atau plot umumnya ditandai dengan jenis-jenis bangunan tertentu yang memiliki fungsi-fungsi tertentu. Umumnya terdapat kesamaan fungsi dalam suatu blok kawasan tertentu, walau dalam beberapa kasus, dijumpai fungsi-fungsi tambahan akibat adanya transformasi atau perubahan. Blok-blok ini pada kawasan kota bersejarah umumnya masih dijumpai walau telah mengalami transformasi, dan pada wilayah tertentu, yakni kota-kota yang lebih tua, hanya dijumpai sisa-sisanya bahkan hilang sama sekali dan menyisakan data yang dalam arkeologi disebut dengan toponimi atau nama 
tempat, kawasan. Blok atau plot pada kota eks Keresidenan Kedu ditandai dengan bentuk-bentuk persegi sesuai dengan jaringan jalan grid pada pusat kotanya, sedangkan blok-blok kawasan pada sisi lainnya seperti pada Kota Magelang, Temanggung, dan Wonosobo serta Purworejo menyesuaikan dengan kontur bentang lahannya yang merupakan daerah perbukitan dan dengan bentang lahan sungai yang cenderung organis (lihat Lampiran).

Unsur alami, jaringan jalan, dan blok kawasan merupakan tiga elemen morfologis kota yang membentuk wajah kota secara umum (urban tissue atau city shape). Ketiga unsur ini saling terkait dengan lainnya, terutama unsur alami yang dalam banyak hal mempengaruhi bentuk jaringan jalan atau bentuk blok kawasannya. Bangunan dan struktur-struktur merupakan bagian dari unsur morfologi kota yang membentuk bagian paling detil dan menunjukkan ciri-ciri yang menunjukkan identitas pada kota-kota eks Keresidenan Kedu. Unsur bangunan atau detil dari struktur tidak begitu nampak dari citra satelit kecuali bangunan-bangunan masif yang membentuk landmark tertentu dan hampir tidak ada bangunan yang begitu dominan pada kota-kota eks Keresidenan Kedu.

Kota-kota eks Keresidenan Kedu ciri-ciri bangunan yang dominan adalah bangunan kolonial dan bangunan modern saat ini. Bangunan-bangunan tradisional hampir dipastikan sudah tidak dijumpai lagi kecuali bangunan kabupaten dan pendopo yang masih memiliki dan diupayakan dengan bentuk tradisional dan menjadi penanda bangunan yang khas. Kota Purworejo, Temanggung, Kebumen, dan Wonosobo masih memiliki bentuk bangunan kabupaten dengan mempertahankan ciri tradisionalnya.

Ciri-ciri bangunan kota eks Keresidenan Kedu juga ditonjolkan dengan bangunan-bangunan kolonialnya. Kota eks Keresidenan Kedu dapat dikatakan merupakan kota-kota kolonial. Kota kolonial tidak ditunjukkan dari dimensi atau bentuk jalannya atau kedekatan dengan lingkungannya, namun lebih dominan dari berbagai jenis bangunan dengan berbagai fungsinya. Berbagai jenis bangunan dengan gaya arsitekturnya yang khas merupakan bagian dari data arkeologi inilah yang paling mendapat perhatian. Seperti telah diuraikan di atas, ciri-ciri bangunan kolonial dengan berbagai fungsi banyak memberikan citra kawasan kolonial yang sangat kental pada kota eks Keresidenan Kedu.

Ciri kota kolonial pada kota-kota eks Keresidenan Kedu pada saat ini mendapat tantangan yang sangat masif sebagai dampak dari pembangunan modern yang progresif dan terkadang tanpa arah. Banyak dari bangunanbangunan kuno, banyak pula yang merupakan warisan atau cagar budaya, telah berubah atau hilang sama sekali, bahkan pada pusat kotanya sekalipun.

Kawasan kota bersejarah yang dibuktikan dengan jejak-jejak sejarah dan arkeologinya, juga menunjukkan adanya satu proses hakiki yang tidak dapat dilepaskan, yakni transformasi. Kawasan kota bersejarah dengan sendiri merupakan kawasan "multi layer" yang dibentuk dengan berbagai proses aktivitas manusia dan alam dari waktu ke waktu (Bandarin, 2015, hlm. xiv-xv). Transformasi bermakna adanya perkembangan dan perubahan pada elemen morfologinya. Jaringan jalan menjadi berkembang, berubah atau hilang sama sekali, Kawasan berkembang, berubah fungsinya, atau hilang sama sekali. Bangunan dan fasilitas fisik lainnya pun berkembang atau berubah fungsinya, 
atau dihilangkan serta dibangun kembali dengan bentuk dan fungsi yang berbeda sama sekali.

Transformasi dapat disebabkan oleh beberapa faktor yakni dinamika aktivitas manusia yang sangat dipengaruhi oleh perubahan zaman dan dinamika alam (Bandarin, 2015). Aktivitas manusia terkaitan dengan multi aspek baik kehidupan sosial, demografi, budaya, ekonomi, politik dan keagamaan yang berubah dari masa ke masa. Salah satu contoh perubahan yang masif adalah pertumbuhan demografi (peningkatan jumlah penduduk) yang menyebabkan perubahan besar terhadap tata guna lahan dan kawasan.

Demikian pula halnya dengan kota-kota eks Keresidenan Kedu, hampir semua kotanya telah berubah dengan drastis walaupun unsur inti dari pusat kota berupa elemen Catur Tunggal tetap dipertahankan atau masih tersisa. Terlihat dalam proses perjalanan waktu, kota tradisional berubah menjadi kota kolonial dan kota kolonial kemudian berubah menjadi kota-kota yang sekarang kita temui, kota-kota pasca kemerdekaan.

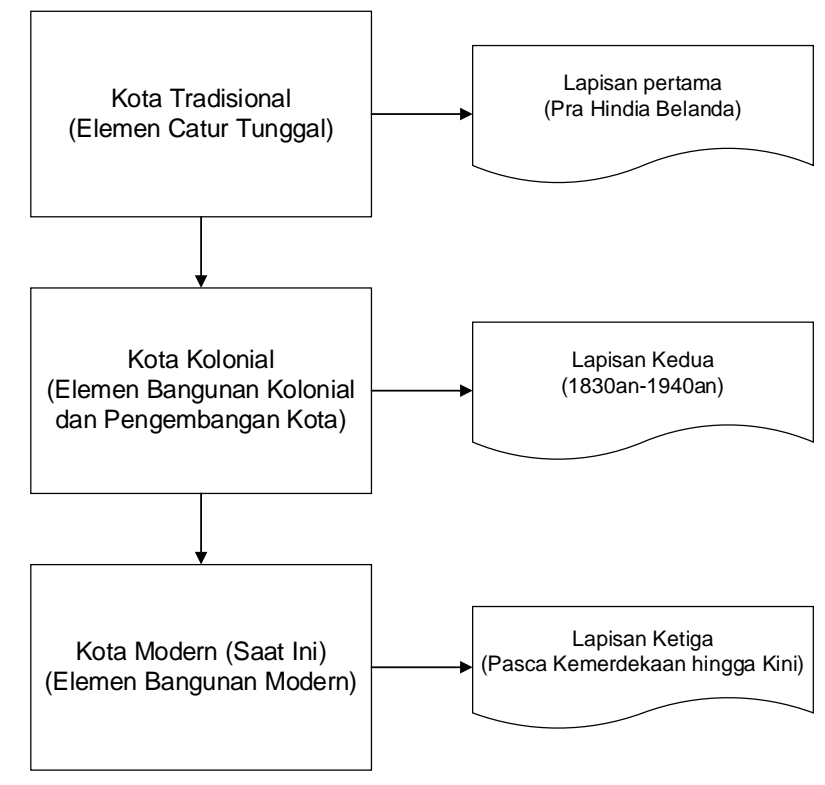

Gambar 10. Skema lapisan kota-kota eks Keresidenan Kedu (Sumber: Penulis)

Menurut penulis setidaknya terdapat tiga lapisan atau layer pada kota-kota eks Keresidenan Kedu seperti telah diungkapkan di bagian awal, yakni lapisan kota tradisional atau pra-kolonial, lapisan kota kolonial, dan lapisan kota saat ini. Terdapat beberapa pendapat tentang sejarah transformasi kota-kota di Indonesia dan penyebutan lapisan-lapisan sejarah kota seperti diungkapkan oleh Nas (1986, hlm. 5-13) dan Zahnd (2008, hlm. 1-46), namun penulis melakukan penafsiran tersendiri terhadap lapisan sejarah tranformasi kota seperti nampak pada Gambar 10.

Lapisan-lapisan ini terjadi karena proses kesejarahan seperti yang telah diuraikan diatas. Proses kesejarahan sendiri merupakan proses yang terjadi meliputi berbagai aspek yang saling terkait. Setiap lapisan sejarah tersebut 
memberikan dasar bagi perkembangan dan perubahan pusat kota eks Keresidenan Kedu.

Lapisan pertama kota tradisional atau lapisan kota pra-kolonial secara arkeologis nampak dari peninggalan morfologi kota yang berupa elemen asli catur tunggal. Elemen ini adalah elemen paling dasar dari perkembangan kota dan agaknya berevolusi dari bentuk-bentuk yang lebih kuno.

Lapisan kedua kota kolonial secara arkeologis nampak dari peninggalanpeninggalan bangunan, jaringan jalan atau jaringan transportasi lainnya, serta plot atau kawasan-kawasan yang kemudian menjelma menjadi pemukimanpemukiman yang lebih berkembang. Dalam konteks ini banyaknya bangunanbangunan atau fasilitas kolonial memberikan ciri yang paling mendasar. Lapisan ini merubah lapisan pertama dengan menggantikan bentuk-bentuk tradisional menjadi bentuk-bentuk kolonial pada tata ruangnya, walaupun secara mendasar bentuk dasar dari pusat kota tidak mengalami perubahan.

Kota-kota eks Keresidenan Kedu semakin kental menjadi kota kolonial dengan banyaknya bangunan dengan gaya campuran tradisional dan eropa dalam beberapa tahapan yakni setelah tahun 1870-an setelah diberlakukannya undangundang liberalisme dan kemudian pada tahun 1900-an ketika diberlakukannya politik etis di Hindia-Belanda. Liberalisme atau swastanisasi mendukung semakin tumbuhnya pemukiman penduduk Eropa dan fasilitas-fasilitas perekonomian seperti pabrik dan jaringan kereta api. Sedangkan pembaruan pada tahun 1900-an mendukung tumbuhnya beragam fasilitas yang lebih beragam seperti pendidikan dan hiburan. Menjelang berakhirnya pemerintahan kolonial pada tahun 1940-an dapat dikatakan kota-kota tradisional telah berkembang dan berubah menjadi kota-kota kolonial.

Lapisan ketiga secara arkeologis nampak dari perubahan yang signifikan terhadap lapisan pertama dan kedua. Lapisan ketiga adalah lapisan kota modern atau lapisan kota pasca kemerdekaan. Lapisan ini adalah lapisan sejarah saat ini, yang tengah berjalan dan memiliki arah perjalan ke masa depan. Lapisan inilah yang nampak saat ini, dengan meliputi sisa-sisa peninggalan pada lapisan satu dan dua. Lapisan pertama masih tetap dipertahankan dengan masih terjaganya elemen catur tunggal. Namun lapisan kedua menjadi berangsur-angsur hilang dengan bentuk-bentuk perkembangan bangunan-bangunan yang semakin modern dan tidak memiliki arah kebijakan pembangunan yang selaras dan memperhatikan nilai-nilai tradisional ataupun kesejarahan. Menurut Daud Aris Tanudirjo (2006, hlm. 1-7) budaya baru dengan gaya hidup baru yang lebih matrelialis serta konsumtif menyebabkan eksistensu sumber daya budaya ini yang sarat dengan berbagai nilai kesejarahan, pendidikan dan kebudayaan dengan mudah dapat dikorbankan atau hilang karena adanya kepentingan komersial. Dalam konteks ini dapat terlihat banyaknya bangunan-bangunan pada masa kolonial yang kemudian telah berubah atau hilang sama sekali.

Meskipun lapisan kota modern ini menutupi atau secara berangsur menghilangkan lapisan-lapisan sejarah sebelumnya, sisa-sisa bukti sejarah dan arkeologisnya masih dapat diamati hingga saat ini. Melalui pengamatan morfologis kota di atas dapat diketahui bahwa unsur bangunan merupakan unsur paling rawan yang senantiasa berubah seperti halnya dengan kondisi pada kotakota eks keresidenan Kedu. Namun secara makro terkait dengan morfologi kota 
masih nampak unsur-unsur pembentuk kota yakni wajah kota yang disusun dari unsur alami, jaringan jalan, dan rupa-rupa kawasan. Kota-kota eks Keresidenan Kedu yang diteliti masih menunjukkan ciri-ciri asli, setidaknya nampak dari wilayah pusat kotanya.

Dengan demikian, pelestarian sebuah kawasan seyogyanya tidak saja memperhatikan struktur atau bangunan sebagai salah satu bagian dari elemen kota, namun hendaknya memperhatikan fitur-fitur yang lain seperti jaringan jalan, blok-blok kawasan serta keberadaan natural context sebagai bagian terpadu dan merupakan satu kesatuan kawasan yang menyusun sebuah "wajah" kota bersejarah.

\section{KESIMPULAN}

Kota-kota eks Keresidenan Kedu dengan ciri-ciri arkeologi atau ciri budayanya menunjukkan identitasnya sebagai kawasan perkotaan bersejarah dengan nilai kesejarahan dan budaya yang kuat. Lapisan-lapisan budaya seperti yang nampak pada elemen-elemen kota dengan peninggalan arkeologis yang berjenjang dari bangunan hingga ke dalam bentuk tata kota yang khas menunjukkan keberadaan nilai-nilai tersebut.

Berdasarkan kajian morfologi perkotaan, kota-kota eks Keresidenan Kedu juga memiliki elemen-elemen yang dalam banyak hal sama dengan kajian arkeologi perkotaan, hanya saja kajian morfologi kota dapat membantu memberikan perspektif yang lebih luas dan integratif bagaimana elemen atau unsur-unsur kota pada dasarnya merupakan satu kesatuan yang membentuk wajah kota. Perspektif ini dalam arkeologi perkotaan belum dilihat secara lebih seksama.

Dalam perspektif arkeologi perkotaan, kota-kota bersejarah, dalam hal ini kota-kota eks Keresidenan Kedu, akan memperhatikan elemen bangunanbangunannya, struktur-struktur dalam perkotaan, toponimi-toponimi yang menunjukkan fungsi ruang tertentu, dan tentunya satu kesatuan diantara elemenelemen tersebut di atas. Namun, dalam perpesktif morfologi perkotaan maka akan ditambahkan pengamatan terhadap jaringan jalan, natural context yakni elemenelemen alam yang merupakan bagian yang tidak dapat dilepaskan dari kota, serta urban tissue atau wajah kota yang tersusun dari semua elemen morfologi kota sebagai bagian yang saling bertautan. Elemen jaringan jalan, baik mengenai bentuk maupun hirarki jalan, keberadaan elemen alam seperti sungai, gunung, serta bentuk alam lainnya dalam kajian arkeologi perkotaan seringkali belum dilihat sebagai data arkeologi yang penting.

Semakin pudarnya peninggalan arkeologis atau warisan budaya pada kota-kota tersebut tentunya menjadi keprihatinan tersendiri akan arah identitas kuat yang dimilikinya. Sangat disayangkan jika kemudian ciri atau identitas kotakota eks Keresidenan Kedu kemudian menjadi hilang tak menyisakan bentuknya sama sekali. Tidak dapat dipungkiri bahwa bangunan-bangunan telah banyak berubah, beralih fungsi atau hilang sama sekali, namun perspektif morfologi kota memberikan harapan pada kita bahwa wajah kota secara keseluruhan masih nampak dengan baik di kota-kota eks Keresidenan Kedu, terutama sekali pusat kotanya. 
Upaya pelestarian terpadu kawasan warisan budaya perkotaan yang tentunya memperhatikan seluruh elemen pembentuk kota sebagai satu kesatuan sudah seharusnya menjadi pertimbangan pula bagi arah kebijakan pembangunan daerah. Kota sebagai wujud dari warisan budaya seperti nampak pula pada kotakota eks Keresidenan Kedu memiliki sumberdaya budaya perkotaan yang sarat dengan identitas lokal dan sejarah yang kuat. Hal ini tentunya dapat menjadi modal identitas yang kuat bagi kota-kota itu sendiri ditengah kuatnya arus globalisasi dan komersialisasi. 


\section{DAFTAR PUSTAKA}

Adrisijanti, Inajati. (1998). Kota Yogyakarta dan Beberapa Kota Pendahulunya. Berkala Arkeologi, 18(2).

Adrisijanti, Inajati. (2000). Arkeologi Perkotaan Mataram Islam. Yogyakarta: Penerbit Jendela.

Badan Perencana Pembangunan Daerah Tingkat II Purworejo. (1982). Sejarah Bagelen hingga Kabupaten Purworejo Dari Sejak Mataram Purba hingga Masa Kini. Bappeda Tk II Purworejo.

Bandarin, Francesco and Oers, Ron van (ed.). (2015). Reconnecting the City. The Historic Urban Landscape Approach and The Future of Urban Heritage. Wiley Blackwell.

Chawari, M. (2010). Berbagai Bentuk Pemanfaatan Bangunan Indis Di Kota Malang: Pemikiran Awal Tentang Pengelolaan Bcb. Berkala Arkeologi, 30(1), 92104. https://doi.org/10.30883/jba.v30i1.399

Handinoto. (1992). Alun-Alun. Jurnal Dimensi Arsitektur, September 1992, 1-15.

Ikaputra, (1995). A Study on the Contemporary Utilization of the Javanase Urban Heritage and its Effect on Historicity: An Attempt to Introduce the Contextual Adaptability into the Preservation of Historic Enviroment of Yogyakarta. The Course of Enviromental Engineering Graduate School of Engineering Osaka University. Japan.

Jannati, Nurul. (2005). Tata Kota Wonosobo Awal Abad XIX - Pertengahan Abad XX TU. (Skripsi). Yogyakarta: Fakultas Sastra, Universitas Gadjah Mada.

Mundardjito. (1995). Kajian Kawasan: Pendekatan Strategis dalam Penelitian Arkeologi di Indonesia Dewasa ini. Berkala Arkeologi, Edisi Khusus. Manusia dalam Ruang: Studi Kawasan dalam Arkeologi.

Musadad. (2002). Kota Kolonial di Indonesia. Buletin Artefak, Edisi No.24, Agustus 2002.

Musadad. (2001). Dari Pemukiman Benteng ke Kota Administratif: Tata Ruang Kota Purworejo, 1831-1930. (Thesis). Yogyakarta: Program Pasca Sarjana Fakultas Ilmu Budaya, Universitas Gadjah Mada.

Nas, Peter J.M. (1986). "Intoduction: A General View of the Indonesian Town", dalam Peter J.M. Nas, Peter (ed.) The Indonesian City. Studies in Urban Develompment and Planning. USA: Floris Publications. 
Oliveira, Vitor. (2016). Urban Morphology. An Introduction to The Study of The Physical Form of Cities. Springer.

Prasetyo Aji, Danar. (2013). Saluran Irigasi Kota Leiding Kota Magelang (Tinjauan Bentuk, Jalur, dan Latar Belakang). (Skripsi). Yogyakarta: Jurusan Arkeologi, Fakultas Ilmu Budaya, UGM.

Pratiwo. (2010). Arsitektur Tradisional Tionghoa dan Perkembangannya. Yogyakarta: Penerbit Ombak.

Rizqi, Muhammad Fariz. (2013). Tata Kota Temanggung dan Faktor-Faktor Pendukungnya Tahun 1834 -1942. (Skripsi). Yogyakarta: Jurusan Arkeologi, Fakultas Ilmu Budaya, UGM.

Sharer, Robert J. dan Wendy Ashmore. (1993). Archaeology, Discovering Our Past. $2^{\text {nd }}$ edition. California: Mayfield Publishing Company.

Sunaryo, Rony Gunawan, dkk. (2013). Colonial and Traditional Urban Space in Java: A Morphological Study of Ten Cities". Dimensi (Journal of Architecture and Built Enviroment), Vol 40, No.2 Desember 2013, 77-88.

Tanudirjo, Daud Aris. (2006). “Pengelolaan Sumber Daya Perkotaan". Artikel. Disampaikan dalam Seminar Pengelolaan Warisan Budaya. Palembang 30-31 Mei 2006.

Wardani, Lestari. (1991). Pola Perkampungan Kota Kudus Lama: Tinjauan Berdasarkan Toponim. (Skripsi). Yogyakarta: Fakultas Sastra, Universitas Gadjah Mada.

Well, Khatirithamby. (1986). The Islamic City: Melaka to Jogjakarta, c. 1500-1800. Modern Asian Studies, Vol. 20, No. 2 1986, pp. 333-351.

Yunus, Hadi Sabari. (2012). Struktur Tata Ruang Kota. Pustaka Pelajar, Yogyakarta.

Zahnd, Markus. (2008). Model Baru Perancangan Kota yang Kontekstual. Kajian Tentang Kawasan Tradisional di Kota Semarang dann Yogyakarta Suatu Potensi Perancangan Kota yang Efektif. Seri Strategi Arsitektur. Yogyakarta: Penerbit Kanisius. 


\section{LAMPIRAN}

\section{Elemen Morfologi Kota Eks Keresidenan Kedu Kota Magelang}

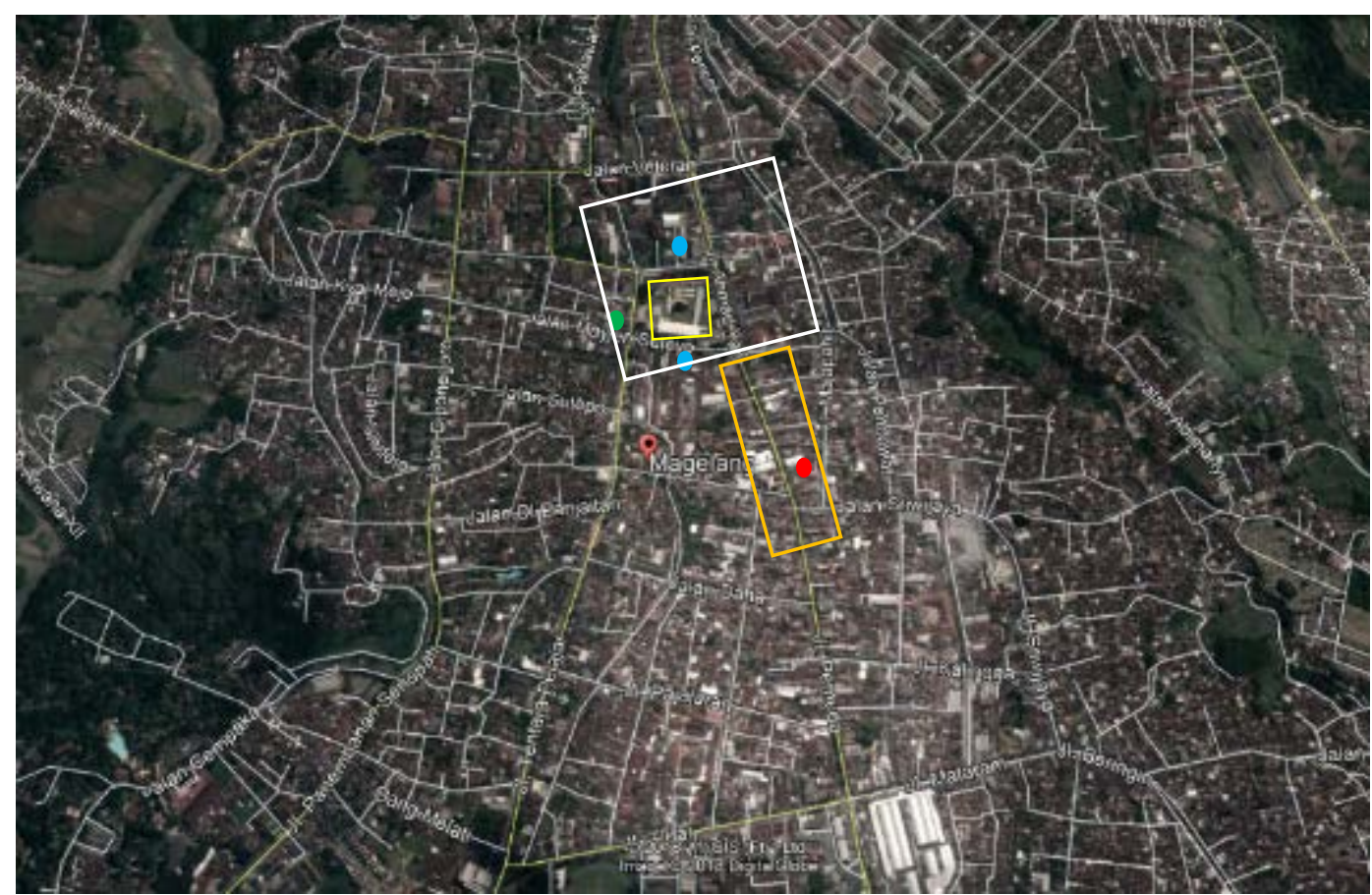

\section{Elemen Inti (warna)}

Alun-Alun

Masjid

Kadipaten dan Regent

Pasar

Bentuk Kotal

Jaringan Jalan

Elemen Alami

Sumber Peta
Elemen Pendukung (Pemukiman lama)

Pemukiman Cina (berdekatan dengan pasar)

Kuning (kotak oranye)

Biru Pemukiman Belanda-Eropa (tersebar dan Merah berdekatan dengan alun-alun; pemukiman militer di sisi utara-timur) (kotak putih)

Geometrik-Grid dengan penyesuaian bentang lahan pada sisi timur-barat.

Gunung Tidar; Sungai Progo dan Elo

Google Earth dengan modifikasi 


\section{Kota Purworejo}

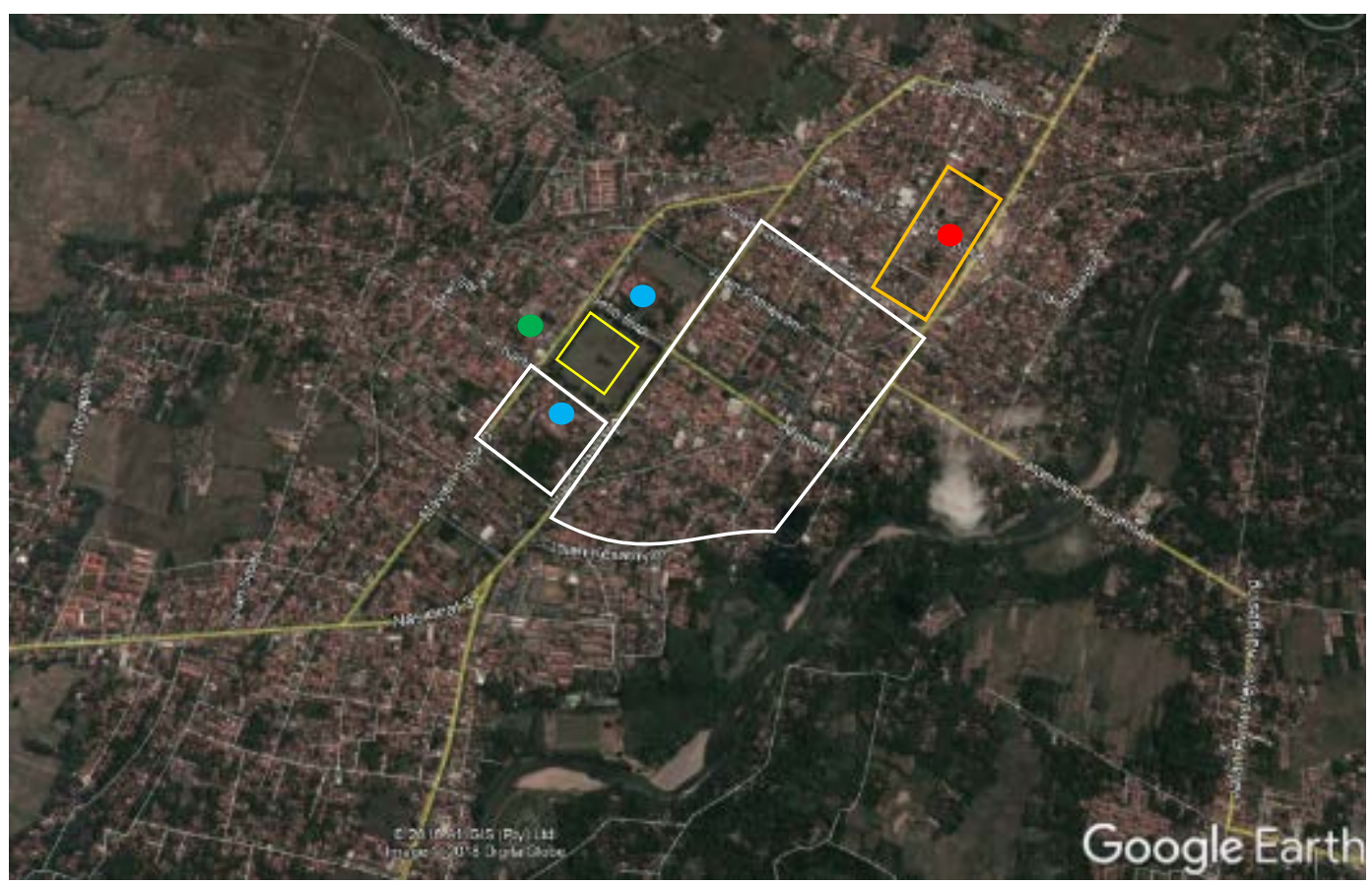

\begin{tabular}{|c|c|c|}
\hline Elemen Inti (warna) & & Elemen Pendukung \\
\hline $\begin{array}{l}\text { Alun-Alun } \\
\text { Masjid } \\
\text { Kadipaten dan Regent } \\
\text { Pasar }\end{array}$ & $\begin{array}{l}\text { Kuning } \\
\text { Hijau } \\
\text { Biru } \\
\text { Merah }\end{array}$ & $\begin{array}{l}\text { Pemukiman Cina (berdekatan dengan pasar) } \\
\text { (kotak oranye) } \\
\text { Pemukiman Belanda-Eropa (tersebar merata di } \\
\text { seluruh kota terutama terkonsentrasi pada sisi } \\
\text { timur kecuali pada sisi barat) (kotak putih) }\end{array}$ \\
\hline $\begin{array}{l}\text { Bentuk Kota/ } \\
\text { Jaringan Jalan }\end{array}$ & \multicolumn{2}{|c|}{$\begin{array}{l}\text { Grid dengan penyesuaian bentang lahan menyerong } \\
\text { menyesuaikan dengan bentang lahan Sungai Bogowonto }\end{array}$} \\
\hline Elemen Alami & \multicolumn{2}{|c|}{ Sungai Bogowonto } \\
\hline Sumber peta & \multicolumn{2}{|c|}{ Google Earth dengan modifikasi } \\
\hline
\end{tabular}




\section{Kota Temanggung}

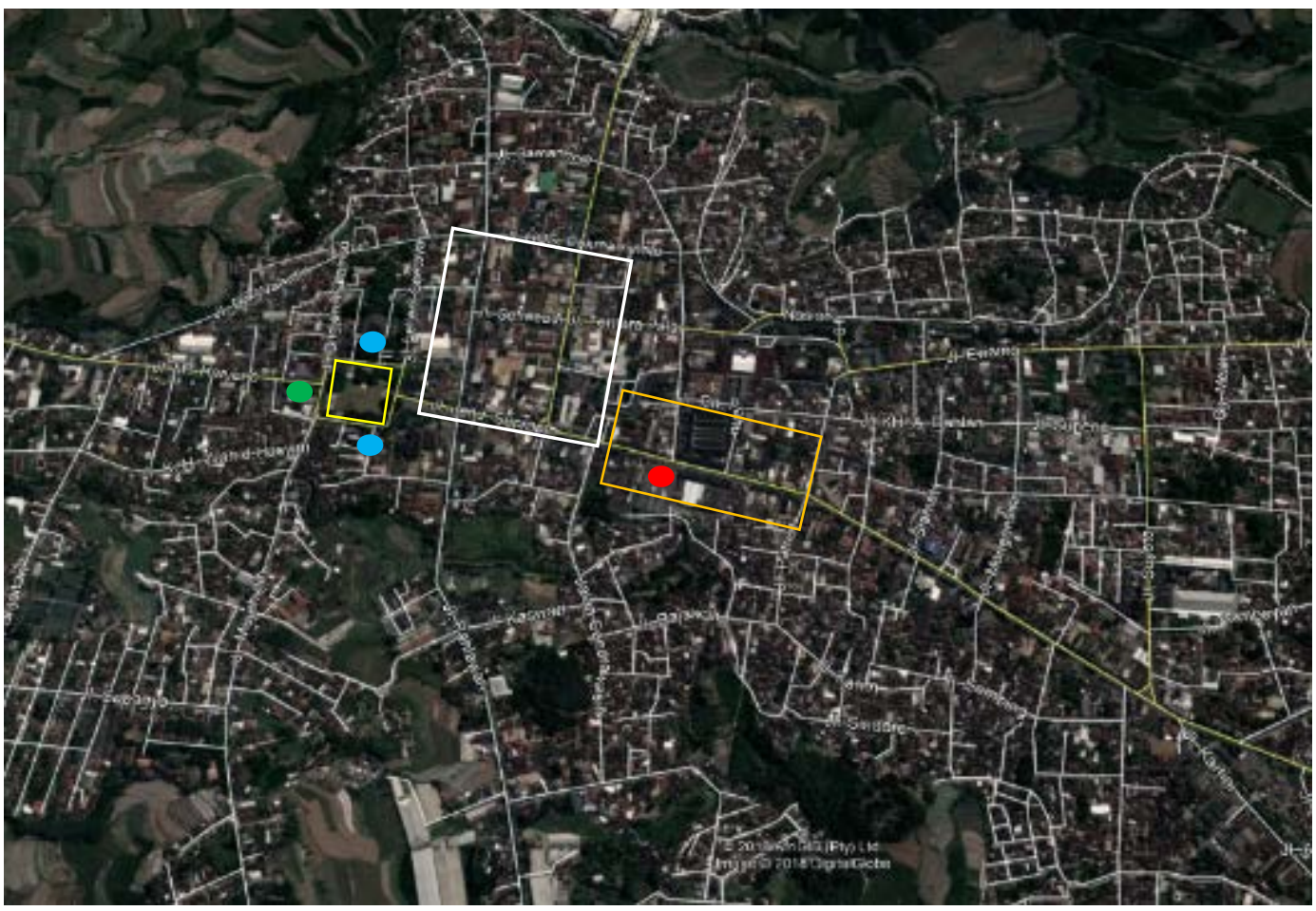

\begin{tabular}{|c|c|c|}
\hline Elemen Inti (Warna) & & Elemen Pendukung \\
\hline Alun-Alun & Kuning & Pemukiman Cina (berdekatan dengan \\
\hline Masjid-Kauman & Hijau & pasar di sisi timur) (kotak oranye) \\
\hline Kadipaten dan Regent & Biru & Pemukiman Belanda-Eropa (berdekatan \\
\hline Pasar & Merah & $\begin{array}{l}\text { dengan alun-alun dan konsentrasi padat } \\
\text { pada sisi timur-laut) (kotak putih) }\end{array}$ \\
\hline $\begin{array}{l}\text { Bentuk Kota/ } \\
\text { Jaringan Jalan }\end{array}$ & \multicolumn{2}{|c|}{$\begin{array}{l}\text { Grid dengan penyesuaian perkembangan kota ke arah } \\
\text { timur. }\end{array}$} \\
\hline Elemen Alami & \multicolumn{2}{|c|}{ Gunung Sindoro-Sumbing; Sungai Progo (Hulu) } \\
\hline Sumber peta & \multicolumn{2}{|c|}{ Google Earth dengan modifikasi } \\
\hline
\end{tabular}




\section{Kota Wonosobo}

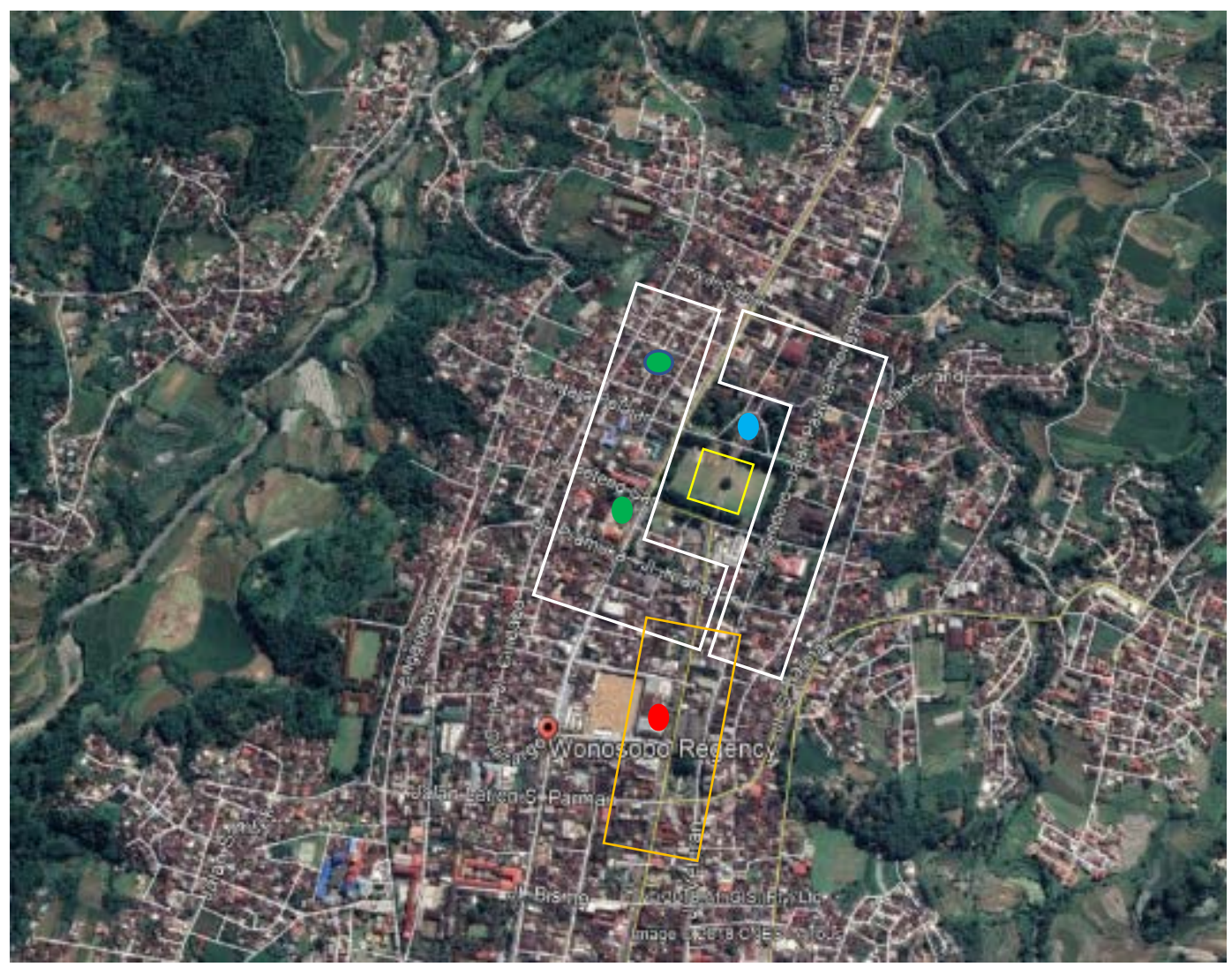

\begin{tabular}{|lll|}
\hline Elemen Inti (Warna) & Elemen Pendukung (Pemukiman lama) \\
\hline $\begin{array}{l}\text { Alun-Alun } \\
\text { Masjid-Kauman }\end{array}$ & Kuning & Pemukiman Cina (berdekatan dengan \\
$\begin{array}{l}\text { Kadipaten dan Regent } \\
\text { Pasar }\end{array}$ & $\begin{array}{l}\text { Bijau } \\
\text { Merah }\end{array}$ & pasar) (kotak oranye) \\
& \multicolumn{2}{c}{ Pemukiman Belanda-Eropa (tersebar } \\
berdekatan dengan alun-alun) (kotak \\
\hline $\begin{array}{l}\text { Bentuk Kota/ } \\
\text { Jaringan Jalan }\end{array}$ & Grid dengan penyesuaian perkembangan sesuai \\
\hline Elemen Alami & bentang lahan \\
\hline Sumber peta & Gunung Sindoro-Sumbing; Sungai Serayu (Hulu) \\
\hline
\end{tabular}




\section{Kota Kebumen}

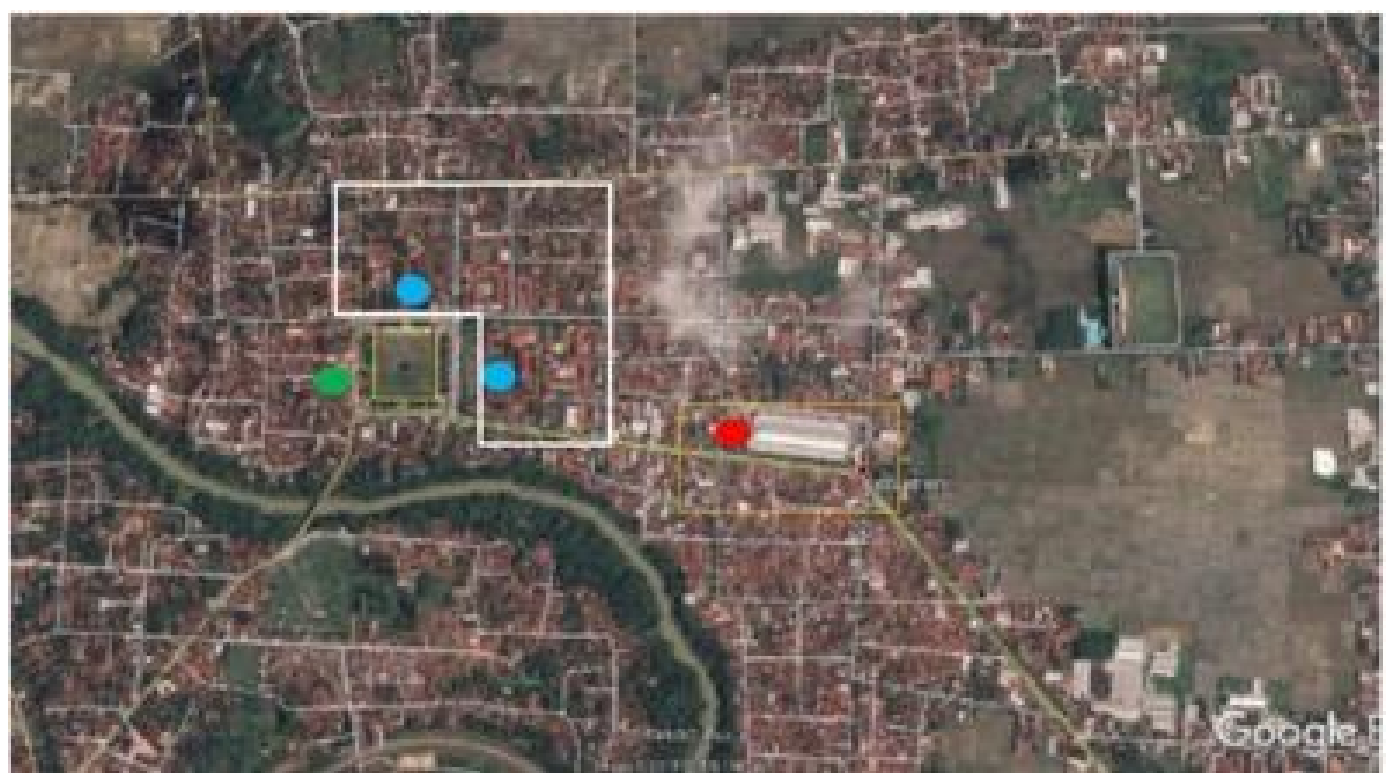

Elemen Inti (Warna)

Alun-Alun

Masjid-Kauman

Kadipaten dan Regent

Pasar

Bentuk Kota/

Jaringan Jalan

Elemen Alami

Sumber peta
Elemen Pendukung (Pemukiman lama)

Kuning Pemukiman Cina (berdekatan dengan

Hijau pasar) (kotak orange)

Biru Pemukiman Belanda-Eropa (tersebar Merah berdekatan dengan alun-alun pada sisi timur) (kotak putih)

Grid dengan penyesuaian perkembangan sesuai bentang lahan di bagian selatan secara organis sepanjang Sungai Luk Ulo Sungai Luk Ulo Google Earth dengan modifikasi 